\title{
PRESIDENTIAL ADDRESS: \\ BOHEMIA, IRELAND AND PAN-CELTICISM
}

\author{
SÉAMUS MAC MATHÚNA
}

Friends and Colleagues, Prosima, Dobra vecher!

It is a great pleasure to be gathered together here in the city of Prríbram in the Czech Republic for the Fifth International colloquium of Societas Celto-Slavica. I welcome you most warmly on behalf of the Society and the Organising Committee. This is the fourth time we have met in a Slavic country, three of our previous meetings having been hosted in Moscow, Dubrovnik and Lodź respectively. We are considering the possibility of holding the sixth colloquium in St. Petersburg in 2012, hopping over 2011 to give colleagues the opportunity of attending the Celtic Congress in Maynooth in 2011, and it may then be time to return to one of the Celticspeaking countries for the seventh colloquium.

\section{I}

It is entirely fitting that we should be here in the Czech Republic in the historic region of Bohemia in which there has been a history of contact and engagement with matters Celtic over many centuries, going back to the Celtic Boii tribe, from which Bohemia, earlier Boihaimum (probably from Boi- and Germ. xaim- 'home of the Boii'), ${ }^{1}$ derives the first part of its name, and continuing to the recent blossoming of interest in Irish and Celtic culture following the Velvet Revolution. It is good to see therefore that the varied programme of lectures which the organisers have prepared for us should include one by the Chair of Conference, Professor Blažek, on Celto-Slavic isoglosses, together with others on the early Celtic and Indo-European lexicon, Irish, Welsh and Breton language and culture, and various papers of a comparative nature on Celtic and Slavic.

\footnotetext{
${ }^{1}$ At the inaugural colloquium of the Societas at Coleraine, Professor Blažek argued that the origin of the toponym was purely Celtic, and explained its meaning as the 'mountain ridge of the Boii' (see Blažek 2010: 22-3).
} 
The Czech connection with Celtic culture is not just limited to the early Boii tribe and the more recent manifestations of Celtomania. We know, for example, that Irish monks settled in various parts of the Moravian Empire during the seventh and eighth centuries, and Bohemia was the home of an important Irish college founded in Prague in the seventeenth century. One of the main streets in the city running from the Old Town to the New is called Hybernska (Irish Street), a name which derives from the Latin word for Ireland (Hibernia) and the college the Irish Franciscans established there in 1629, the College of the Immaculate Conception. The college was founded to relieve the pressure on numbers at the Irish colleges in Louvain and Rome and remained in use by the Franciscans for one hundred and fifty years, until 1786. Irish colleges on the continent during this time provided Irish Catholics with educational opportunities which were not available to them at home and they played a pivotal role in preserving and nurturing Irish learning and culture at a critical time in Irish history.

Among the many interesting things that happened in Prague is the translation into Irish of the influential Introduction à la vie dévote of Saint Francis de Sales (1567-1622), bishop of Geneva and a leader of the Counter-Reformation movement. It was a very popular work which was translated into a number of vernacular languages. The Irish translation, $A n$ bheatha chrábhaidh (The Devout Life), was made by Fr Philip O'Reilly, guardian of the college between 1650 and 1654. Stylistically, the Irish translation is similar to other Counter-Reformation devotional works written or translated into Irish during this period, deviating from the more conservative language of Classical Irish in its use of a simpler more popular idiom which made it accessible to a wider public. ${ }^{2}$

\section{III}

Since the latter part of the sixteenth century and through the seventeenth and eighteenth centuries, particularly following the flight of the Wild Geese at the end of the seventeenth century, large numbers of Irish served in the armies of the great powers of Europe, including the Habsburg Empire. According to a list of names in the Kriegsarchiv in Vienna, there were approximately 1,500 officers of Irish or probable Irish origin in the imperial army between circa 1630 and circa 1830. It has also been

\footnotetext{
2 See Dillon 2006, Mac Craith \& Worthington 2003; more generally on the Irish Franciscans in Prague, see Jennings 1939; Bhreathnach, McMahon \& McCafferty 2005; Millett 1964 (in particular, chapters 2 and 6).
} 
estimated that there were over 100 Austrian field-marshals, generals and admirals of Irish origin, including the illustrious field-marshals, Von Browne, Kavanagh, O'Donnell and De Lacy. Many Irishmen distinguished themselves not only in the army but also in the diplomatic and administrative services and were integrated with the host society and intermarried to form an élite influential group in society. These IrishAustrian-Bohemian émigrés encouraged the establishment of the Irish College in Prague and influenced members of the Catholic AustroBohemian aristocracy to do likewise, such as Count Adalbert von Sternberg who endowed the College's library.

\section{IV}

One of the most distinguished Irish families who served in both the Holy Roman Empire and Austro-Hungary were the Taafes. Sir John Taafe, the first Viscount Taafe, was raised to the Peerage of Ireland in 1628 and his eldest son, Theobald, the second Viscount, was created the Earl of Carlingford. Nicholas Taafe, the second Earl of Carlingford, was killed at the Battle of the Boyne in 1690 fighting on the side of the James II of England. Although his Irish estates were forfeited, his younger brother, Francis Taafe, third Earl of Carlingford, succeeded in having the forfeiture repealed. He was a Field Marshal in the Habsburg Army. On the death of the Fourth Earl, the Earldom of Carlingford became extinct. Nicholas Taafe, the Sixth Viscount Taafe, tried to legally retrieve the estates, finally succeeding in gaining enough recompense to purchase the castle of Ellisschau in West Bohemia which was modelled on that of his Irish estate.

The most famous member of the Taafe family was probably Eduard (Franz Joseph) Taafe (1833-1898), the Eleventh Viscount, who spent two periods as Minister-President of Cisleithania, the Austrian part of the Empire, between 1868 and 1870 and again between 1879 and 1883. His aim was to unite the main nationalities of Austria - the Germans and the Slavs - and to this end he succeeded in persuading the Czechs to abandon abstentionism. He was also a reformer who introduced legislation which increased significantly the franchise and helped in alleviating the democratic deficit. $^{3}$

\footnotetext{
${ }^{3}$ On the Irish in Austria in the period concerned, see Downey 2002.
} 
The rise of romantic nationalism in the late eighteenth century and in the nineteenth century was accompanied by an interest in primitive or 'exotic' cultures and in the search by aspiring nationalities of foundational epics which would underpin their claim to nationhood. One such text, which was to have a profound influence on European literature and culture, was James Macpherson's Ossian. It was translated into most of the languages of Europe, including Czech and Slovak, and as late as 1885, the Czech poet, Julius Zeyer (1841-1901), based his Ossianův návrat (Ossian's Return) on Irish sources. In this connection, I look forward to hearing the paper on Celtic motifs in Zeyer's work which is to be delivered at the conference by Ms Blažková.

\section{VI}

The winds of change blowing in Europe, and the interest in marginal cultures, influenced not only the development of Irish and other nationalisms but also the growth of Pan-Slavic and Pan-Celtic movements. These movements had a mutual influence on each other. The founder of Pan-Slavism was the Slovak poet, philosopher and preacher, Jan Kollár (1793-1852), who held a professorship at the University of Vienna. He published in 1824 the verse epic Slávy Dcera (The Daughters of Slava), a foundation text which inspired the national and culturallinguistic spirit of Slavs in general. The work of other scholars, such as the Slovak linguist Pavel Josef Šafarík (1795-1861), in his landmark study published in 1826, Geschichte der slawischen Sprache und Literatur nach allen Mundarten (History of Slavonic Language and Literature in All Its Dialects), and the Czech historian and politician František Palacký (17981876), who published extracts of a translation of Ossian, confirmed that the Slavic dialects were all related and belonged to one original language. This suggested to them that there was at one time a Slavic national unity. Josef Dobrovský (1753-1839), the father of Czech philology, had already founded Pan-Slavic periodicals through the medium of German, such as Slawin and Botschaft aus Böhmen an alle Slavischen Völker. Palacký and Šafarík assembled the first Pan-Slavic Congress in Prague in June 1848 which was attended by 141 delegates, mostly Austrian Slavs, but also Slavs from Russia and Poland. 
The first movements towards Pan-Celticism began with the foundation of the Academie Celtique (1805-14) and interest burgeoned thereafter so that societies interested in the national affinity between the Celtic peoples grew up in England, Wales and Scotland. In 1838 the Welsh Eisteddfod, held at Abergavenny, was attended by Breton delegates, led by the young nobleman Théodore Hesart de la Villemarqué who had begun collecting and publishing Breton manuscripts and ballads. The first Pan-Celtic Congress was held in Paris in 1867 shortly after the second Pan-Slavic Congress in Moscow. Greetings from the Pan-Slavic Congress were relayed to the new Celtic Congress. Another development of the PanCeltic Congress was The Pan-Celtic Association which was launched in Dublin in 1900. At the meeting of Congress in Dublin 1901, the Polish cultural activist, Alfons Parczewski, delivered a talk entitled 'Slavonic Society for the Dissemination of National Literatures: an Example for the Celtic Nations'.

\section{VIII}

More recently, Czech and former Czechoslovakian Celtic scholars who have made important contributions to Celtic Studies include the linguist and philologist Josef Baudiš (1883-1933), the archaeologist and historian Jan Filip (1900-1981), and modern day scholars such as Václav Blažek and Věra Čapková, together with other younger scholars, some of who are present here today. I should say that the illustrious tradition instituted in the seventeenth century by the Irish Franciscans has continued in Charles University, where, incidentally, both Josef Baudiš and Jan Filip once taught and studied, and where today there is a vibrant centre for Irish Studies, which includes among its programmes the teaching of Old and Modern Irish.

\section{IX}

Our conference here during these next few days, with its coverage of a wide range of topics of Czech and Celtic interest, will hopefully serve to support and develop the scholarly and cultural links between the Celtic countries and the Czech Republic. We are grateful that to have the opportunity to hold this conference in a country which provided such a welcome home and haven for our wandering Irish clerics, scholars and soldiers of the past. 


\section{References}

Bhreathnach, E., McMahon, J., \& J. McCafferty, 2005, The Irish Franciscans, 1534-1990, Dublin: Four Courts Press.

Blažek, V., 2010, 'Etymological Analysis of Toponyms from Ptolemy's Description of Central Europe', in: Brozović Rončević, D., Fomin, M., \& R. Matasović, eds., Celts and Slavs in Central and South-eastern Europe. Proceedings of the Third International Colloquium of Societas CeltoSlavica held at IUC, Dubrovnik, 18-19 September 2008. Studia CeltoSlavica 3, Zagreb: Institute for Croatian Language and Linguistics, 21-45.

Dillon, C., 2006, 'Irish Translation in Continental Europe, 1630-60', in: O'Connor, T., \& M. A. Lyons, eds., Irish in Europe, vol. 3, Dublin, 38394.

Mac Craith, M., \& D. Worthington, 2003, 'Aspects of the Literary Activity of the Irish Franciscans in Prague, 1620-1786', in: O'Connor, T. \& M. A. Lyons, eds., Irish Migrants in Europe after Kinsale, 1602-1820, Dublin: Four Courts Press.

Jennings, B., O. F. M. (Rev.), 1939, 'The Irish Franciscans in Prague', Studies: An Irish Quarterly Review 28.110 (June), 210-22;

Downey, D. M., 2002, 'Wild Geese and the Double-headed Eagle: Irish Integration in Austria c.1630-c.1918', in: Leifer, P., \& E. Sagarra, eds., Austro-Irish Links through the Centuries, Vienna: Diplomatic Academy of Vienna, Favorita Papers, Special Edition, 41-57.

Millett, B., O. F. M., 1964, The Irish Franciscans, 1651-1665, in: Analecta Gregoriana 129, Series Facultatis Historiae Ecclesiasticae: Section B, Roma: Gregorian University Press. 